\title{
NUTRITIVE VALUE AND IN VITRO DIGESTIBILITY OF NON-CONE HOP (HUMULUS LUPULUS L.) BIOMASS
}

\author{
L. K. Rutto ${ }^{1, *}$, V. W. Temu ${ }^{1}$, G. Ferreira ${ }^{2}$ and M. K. Kering ${ }^{1}$ \\ ${ }^{1}$ Agricultural Research Station, Virginia State University, PO Box 9061, Petersburg, VA 23806, USA \\ ${ }^{2}$ Department of Dairy Science, Virginia Tech, 2100 Litton Reaves Hall, Blacksburg, VA 24061, USA \\ *Corresponding Author Email: 1rutto@vsu.edu
}

\begin{abstract}
More than $50 \%$ of hop (Humulus lupulus L.) biomass is discarded as waste. Potentially, this by-product, comprising leaves, bines, and unrecovered cones (non-cone biomass) can be processed into a high value forage. In this study we used classical forage and hop analysis methods to determine the nutritive and chemical properties of non-cone biomass from five (Cascade, Chinook, Newport, Nugget and Zeus) hop cultivars. Cascade had significantly higher crude protein $(p \leq 0.05)$, while ash, starch and sugar content were not statistically different among cultivars. Acid and neutral detergent fiber ranged between $187-295 \mathrm{~g} \cdot \mathrm{kg}^{-1}$ and $274-397 \mathrm{~g} \cdot \mathrm{kg}^{-1}$ of DM, respectively, with Cascade recording significantly $(p \leq 0.05)$ higher fiber than other cultivars. In vitro, dry matter $\left(604-685 \mathrm{~g} \cdot \mathrm{kg}^{-1}\right)$ and NDF $\left(374-478 \mathrm{~g} \cdot \mathrm{kg}^{-1}\right)$ digestibility were significantly $(p \leq 0.05)$ higher in Newport, while true dry matter disappearance $\left(709-793 \mathrm{~g} \cdot \mathrm{kg}^{-1}\right)$ was significantly $(p \leq 0.05)$ lower in Cascade. Variations were also observed in plant metal content with Ca being significantly $(p \leq 0.05)$ lower in Cascade, $\mathrm{K}$ in Nugget, and $\mathrm{S}$ in Zeus, while $\mathrm{Mg}$ was highest in Newport. Overall, crude protein and nonstructural carbohydrate content in hop biomass were comparable, respectively, to alfalfa, and to forage grasses like brome and Kentucky bluegrass, and acid and neutral detergent fiber levels were slightly lower than in alfalfa and legume-grass hays. Digestibility also compared favorably to other forages including legume-grass hays and alfalfa silage. Hop biomass can be a good source of dietary calcium, magnesium, and trace elements, and furthermore was found to contain low levels of lupulone, a compound in cone biomass recommended as a natural alternative to synthetic antibiotics. Our findings suggest non-cone hop biomass may be of significant value as a supplement in livestock nutrition.
\end{abstract}

Key words: Humulus lupulus; Non-cone biomass; Nutritive value; Mineral content; $\alpha$ and $\beta$ acids.

https://doi.org/10.36899/JAPS.2020.4.0093

Published online April 25, 2020

\section{INTRODUCTION}

Hops (Humulus lupulus L.) is a perennial crop grown for the female inflorescence that is a source of organic acids and other compounds essential to beer flavor and aroma. During recovery of the female flowers (cones) for further processing and marketing to the beer industry, large quantities of non-cone biomass in form of leaves and woody stems (bines) are generated.

In commercial hop production, disposal of noncone biomass is an expensive nuisance that is compounded by the reluctance of growers to return hop residue into hop yards for fear of accelerating the spread of pests and disease causing agents. This means leaf and bine biomass is usually removed from the field and transported away from the hop yard, an exercise that translates into significant labor cost and loss of native and added soil nutrients.

Various studies have examined potential applications for non-cone hop biomass including utilization as a sorbent in the recovery of lead (Hejazi, 2001; Gardea-Torresday et al., 2002), cadmium (Partelová et al., 2015) and gold (López et al., 2005) from aqueous solutions, or conversion into biofuel by wet torrefaction (Yang et al., 2015) or slow pyrolysis (Apaydin-Varol et al., 2017). There are also some reports on alternative use as feed or for supplementation of animal diets. Al-Mamun et al. (2009) found that inclusion of $15 \%$ dried non-cone hop residue or $25 \%$ ensiled hop biomass (Al-Mamun et al., 2011) in a mixed hay diet did not significantly impact plasma acetate metabolism in sheep. Production of acetate, an important metabolite in fatty acid and carbohydrate metabolism, largely depends on feed quality (Sutton et al., 2003) and blood acetate content is a useful index in animal nutrition (Pethick et al., 1981). In an earlier study, Statham (1984) found that replacement of Lucerne as a yolk coloring additive with a similar amount of dried hop leaf residue in the diet of laying hens resulted in darker colored yolks without affecting feed intake, egg production, or the taste of eggs and carcasses.

Potential for on-farm utilization of hop non-cone biomass as forage or feed supplement is of particular interest to hops growers in Virginia and the greater midAtlantic who have taken up hop production in response to demand from a growing craft beer industry. According to 
statistics from the Brewers Association (an organization representing small and independent craft brewers), beer production by craft brewers in the United States (U.S.) has increased by more than $200 \%$ in the last 10 years with most growth being observed among regional and microbreweries (Brewers Association, 2018). Owing to small-scale operations and strong regional identity, craft breweries are open to sourcing key ingredients from local suppliers provided quality, quantity and pricing are satisfactory. In Virginia, the state is supportive of the craft beer industry and many landowners have started or are considering growing hops or specialty grains to meet demand by local craft breweries. In a survey conducted by Virginia Cooperative Extension (Siegle and Scoggins, 2017), a majority of respondents have been growing hops for less than three years. Unlike in the Pacific Northwest (PNW), Virginia hop yards are small (1-2 acres on average) and most hop production takes place on farms with mixed crop/animal operations. Such farms would benefit from information on the potential for on-farm utilization of non-cone hop biomass as forage or value addition for sale to neighboring farms. Furthermore, the hop plant lends itself to adoption as a forage source because harvesting (cone separation) is usually done at a central location with non-cone biomass easily stockpiled for further processing and handling. Nationally, value addition to non-cone biomass would greatly benefit major PNW hop growers whose acreage almost solely accounts for production levels $(>44,000$ tons in 2017) that make the U.S. the world's top hop producer (International Hop Growers' Convention, 2017).

Here, we report results on nutritive value, in vitro digestibility, and organic acid chemistry of noncone forage sampled from five hop cultivars.

\section{MATERIALS AND METHODS}

Animal care and use: The Institutional Animal Care and Use Committee of Virginia Tech approved all procedures involving dairy cows for collecting rumen contents (protocol 15-234).

Experimental site and conditions: The data presented here is from the 2017 growing season for materials grown at the Virginia State University Research and Demonstration hop yard located in Randolph Farm (37²13'46" N; 77²6'02" W). Climatic data (Table 1) was recorded on-site using a weather station equipped with HOBO smart sensors and a HOBO RX3000 remote monitoring datalogger (Onset Computers, Bourne, MA).

Plant materials: Non-cone hop biomass was recovered at cone maturity from five cultivars (Cascade, Chinook, Newport, Nugget and Zeus) established in the spring of 2016 using certified rooted cuttings purchased from Great Lakes Hops (Zeeland, MI). The hop yard consists of an $18 \mathrm{ft}(5.5 \mathrm{~m})$ tall trellis system with primary lines running north to south and secondary support lines running east to west. Plant rows are spaced $3.0 \mathrm{~m}$, and plants $1.0 \mathrm{~m}$ apart within rows for a population of approximately 3330 plants per hectare. All cultivars received similar fertilizer, irrigation, and pest and disease management treatments in 2017 with nitrogen (N) applied at a rate equivalent to 110 $\mathrm{kg} \cdot \mathrm{ha}^{-1} \mathrm{~N}$.

Sampling and sample processing: At cone maturity (August - September), bines were cut and transported to a central location where cones were separated from noncone biomass with the help of a Hopster 5P hops harvester (Hopsharvester LLC, Honeye, NY). A tarp was used to trap all non-cone biomass generated during harvest and both leaf and bine material was consolidated per crown (plant) with four replicates per cultivar based on a completely randomized sampling design. Fresh biomass from individual plants was weighed then transferred into labeled burlap sacks and dried to constant weight at $72^{\circ} \mathrm{C}$ using a Grieve ${ }^{\circledR}$ oven. Dry matter (DM) yield was recorded before samples were rough-ground to pass a $4 \mathrm{~mm}$ sieve. Subsamples were further ground with a Wiley mill to $2 \mathrm{~mm}$ before transfer to the lab for analysis.

Forage analysis: Ash concentration was determined following AOAC method 942.05 (AOAC International, 2016) by combusting samples in a furnace for $3 \mathrm{~h}$ at $600^{\circ} \mathrm{C}$. Crude protein concentration was calculated as a percentage $(\mathrm{N} \times 6.25)$ after $\mathrm{N}$ determination by combustion (method 990.03; AOAC International, 2016) using a Vario El Cube CN analyzer (Elementar Americas Inc., Mount Laurel, NJ). Neutral detergent fiber (NDF) and acid detergent fiber (ADF) concentrations were determined using an Ankom 200 Fiber Analyzer (Ankom Technology, Macedon, NY) with sodium sulfite and $\alpha$ amylase included for NDF analysis. Starch concentrations were determined using the acetate buffer method (Hall, 2009) with $\alpha$-amylase from Bacillus licheniformis (Ankom Technology) and amyloglucosidase from Aspergillus niger (E-AMGDF; Megazyme International, Wicklow, Ireland). Sugar concentrations were determined as total ethanol/watersoluble carbohydrates as described by Hall et al. (1999).

In vitro dry matter digestibility (IVDMD), in vitro true DM disappearance (IVTDMD), and in vitro NDF digestibility (IVNDFD) were determined using a DaisyII rotating jar incubator (Ankom Technology, Macedon, NY) following procedures described by Ferreira and Mertens (2005).

For mineral content, non-cone biomass samples were analyzed by inductively coupled plasma atomic emission spectrometry (ICP-AES) for calcium (Ca), potassium $(\mathrm{K})$, sulfur $(\mathrm{S})$, and magnesium $(\mathrm{Mg})$ following AOAC Official Method 953.01 (AOAC International, 2016). 
Alpha and $\boldsymbol{\beta}$-acid analysis: Analyses of $\alpha$ and $\beta$-acid content in non-cone hop biomass was done by spectrophotometry. Briefly, $15 \mathrm{~g}( \pm 0.01)$ samples of ground non-cone biomass were transferred into $1000 \mathrm{ml}$ extraction bottles to which $300 \mathrm{ml}$ of toluene was added. The vessels were stoppered and shaken for $30 \mathrm{~min}$ on a rotary shaker. After $30 \mathrm{~min}$, samples were centrifuged at $2000 \mathrm{rpm}$ for $5 \mathrm{~min}$ and allowed to settle for $10 \mathrm{~min}$ before a $5 \mathrm{ml}$ clear aliquot was drawn. Samples were diluted and absorbance determined using a spectrophotometer as described in methods published by the American Society for Brewing Chemists (ASBC, 2011). Absorbance readings were used to compute $\alpha$ and $\beta$ acid content in DM for the different samples.

Statistical analysis: A one-way analysis of variance using the Proc-ANOVA function in SAS (v 9.4) was performed on all variables. Variety was taken as a factor with five levels and mean comparisons were done using Tukey's HSD test $(p \leq 0.05)$.

\section{RESULTS}

Dry matter yield and partitioning: Biomass yield ranged from a projected maximum $4.1 \mathrm{Mg} \cdot \mathrm{ha}^{-1}$ in Zeus to a low of $1.8 \mathrm{Mg} \cdot \mathrm{ha}^{-1}$ in Newport (Figure 1). Statistically, total biomass in Zeus was significantly higher per unit area than in the other four cultivars and significantly lower in Newport, with no significant differences observed between Cascade, Chinook and Nugget. Noncone biomass followed a similar trend with Zeus recording significantly higher yield than all the other cultivars (Figure 1). Non-cone biomass DM yield ranged between $230-290 \mathrm{~g} \cdot \mathrm{kg}^{-1}$ of fresh biomass, which was slightly higher than the $220-230 \mathrm{~g} \cdot \mathrm{kg}^{-1}$ (data not shown) recorded for cone biomass at harvest (Table 2).

For all cultivars, DM partitioning favored noncone over cone biomass. With only $18 \%$ cone biomass, the proportion of non-cone biomass was significantly higher in Newport than in Cascade, Nugget, and Zeus, but similar to Chinook (28\%). Nugget and Zeus at 36\% and $37 \%$ cone biomass, respectively, recorded significantly lower non-cone biomass than the other three cultivars (Figure 2.)

Nutritive value of non-cone hop biomass: Crude protein (CP) in non-cone biomass was significantly higher in Cascade, while readings for Zeus were significantly lower than for all other varieties. There were no significant differences in ash content $\left(129-146 \mathrm{~g} \cdot \mathrm{kg}^{-1}\right)$ among the five cultivars (Table 2). Water soluble carbohydrates (sugar and starch) levels in non-cone hop biomass was also variable. Sugar content ranged from a high of $78.7 \mathrm{~g} \cdot \mathrm{kg}^{-1}$ of DM in Nugget to a low of 49.7 $\mathrm{g} \cdot \mathrm{kg}^{-1}$ in Cascade with no significant difference in content among the top four varieties. Starch content was much lower ranging from $11.9-21.6 \mathrm{~g} \cdot \mathrm{kg}^{-1}$ of DM with no significant differences observed among varieties (Table 2). Acid detergent fiber and aNDF ranged between 187 $295 \mathrm{~g} \cdot \mathrm{kg}^{-1}$ and $274-397 \mathrm{~g} \cdot \mathrm{kg}^{-1}$ of DM, respectively. For both ADF and aNDF, Cascade had significantly higher fiber than all the other cultivars, while fiber content in Nugget was numerically the lowest among all five cultivars (Table 2). For plant metals measured, content ranged between $29.1-37.8 \mathrm{~g} \cdot \mathrm{kg}^{-1}$ of DM for $\mathrm{Ca}, 19.5-26.6$ $\mathrm{g} \cdot \mathrm{kg}^{-1}$ for $\mathrm{K}$, 1.9-2.6 $\mathrm{g} \cdot \mathrm{kg}^{-1}$ for $\mathrm{S}$, and $6.9-8.4 \mathrm{~g} \cdot \mathrm{kg}^{-1}$ for $\mathrm{Mg}$. Among cultivars, significant variations in metal content were observed with $\mathrm{Ca}$ being significantly lower in Cascade, $\mathrm{K}$ in Nugget, and $\mathrm{S}$ in Zeus, while Mg was highest in Newport (Table 2).

In vitro digestibility of non-cone hop biomass: In vitro dry matter digestibility (IVDMD) ranged from a high of $686 \mathrm{~g} \cdot \mathrm{kg}^{-1}$ in Newport to a low of $605 \mathrm{~g} \cdot \mathrm{kg}^{-1}$ in Cascade and Chinook. Newport IVDMD was significantly higher than in all the varieties except Nugget, although there were no significant differences in IVDMD among Nugget, Cascade, Chinook and Zeus. True dry matter disappearance (IVTDMD) in Cascade at $709 \mathrm{~g} \cdot \mathrm{kg}^{-1}$ was significantly lower than in the other four cultivars. In vitro NDF digestibility (IVNDFD) followed a similar trend as IVDMD with significantly higher digestibility observed in Newport $\left(478 \mathrm{~g} \cdot \mathrm{kg}^{-1}\right)$. Digestibility among the other four varieties (374-419 $\left.\mathrm{g} \cdot \mathrm{kg}^{-1}\right)$ were numerically, but not statistically different.

Alpha and $\boldsymbol{\beta}$-acid content in non-cone hop biomass: Different levels of $\beta$-acid (lupulone) were present in noncone biomass of all five cultivars. However, no significant differences were observed between cultivars owing to large within-cultivar variations in $\beta$-acid content (Figure 3). Among cultivars, $\beta$-acid content was highest in Nugget and Chinook $\left(1.7 \mathrm{mg} \cdot \mathrm{g}^{-1}\right.$ of DM) and lowest in Newport $\left(0.9 \mathrm{mg} \cdot \mathrm{g}^{-1}\right.$ of DM). Alpha acids were present in measurable quantities only in Newport and Zeus with content in Newport (1.1 $\mathrm{mg} \cdot \mathrm{g}^{-1}$ of $\left.\mathrm{DM}\right)$ being significantly higher than in Zeus with $0.2 \mathrm{mg} \cdot \mathrm{g}^{-1}$ of DM (Figure 3). 


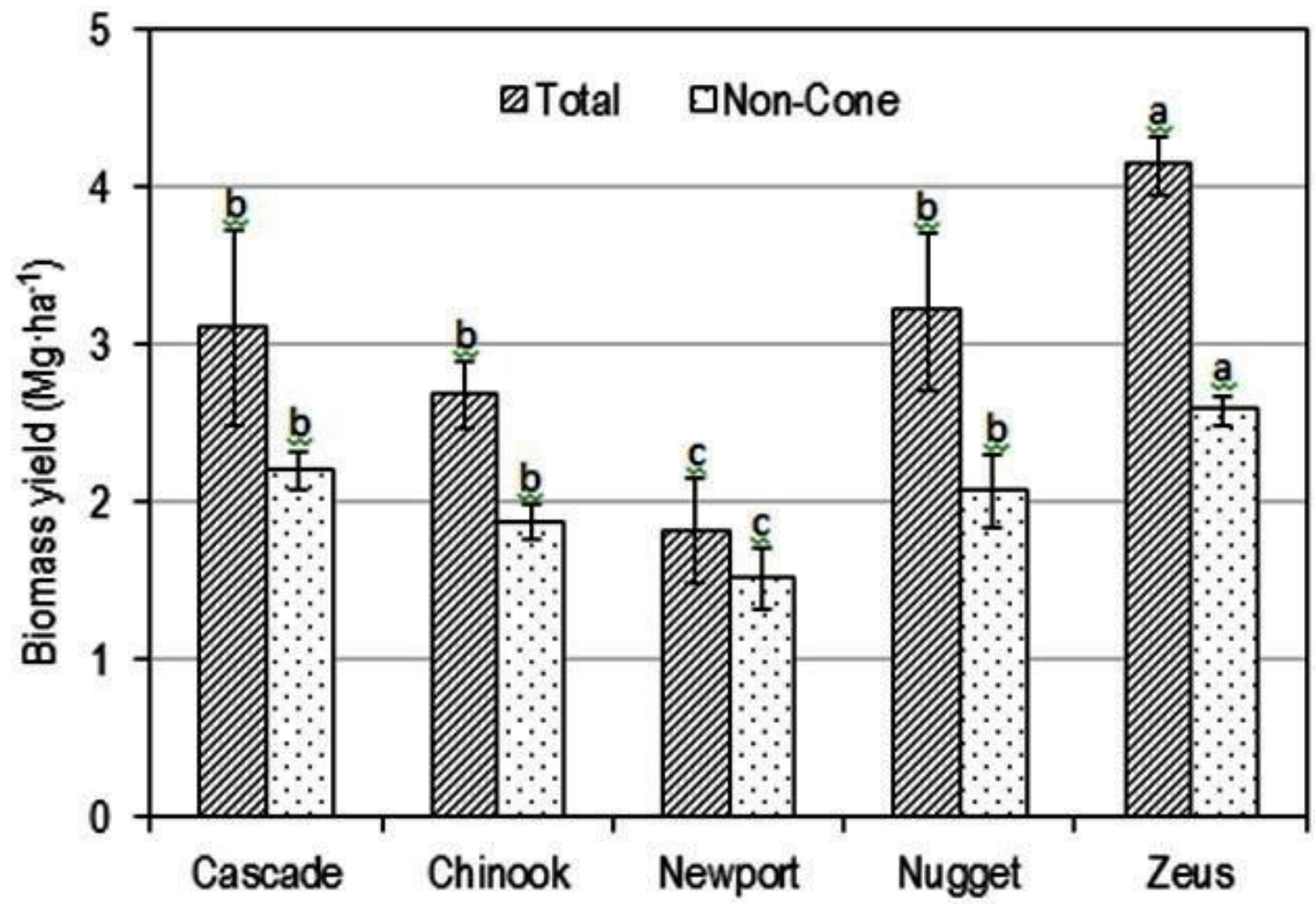

Figure 1. Total and non-cone biomass yield from five hop (Humulus lupulus L.) cultivars grown under Virginia conditions. Bars represent standard error of the mean $(n=4)$ and letters denote significant difference between varieties (within biomass type) at $p \leq 0.05$.

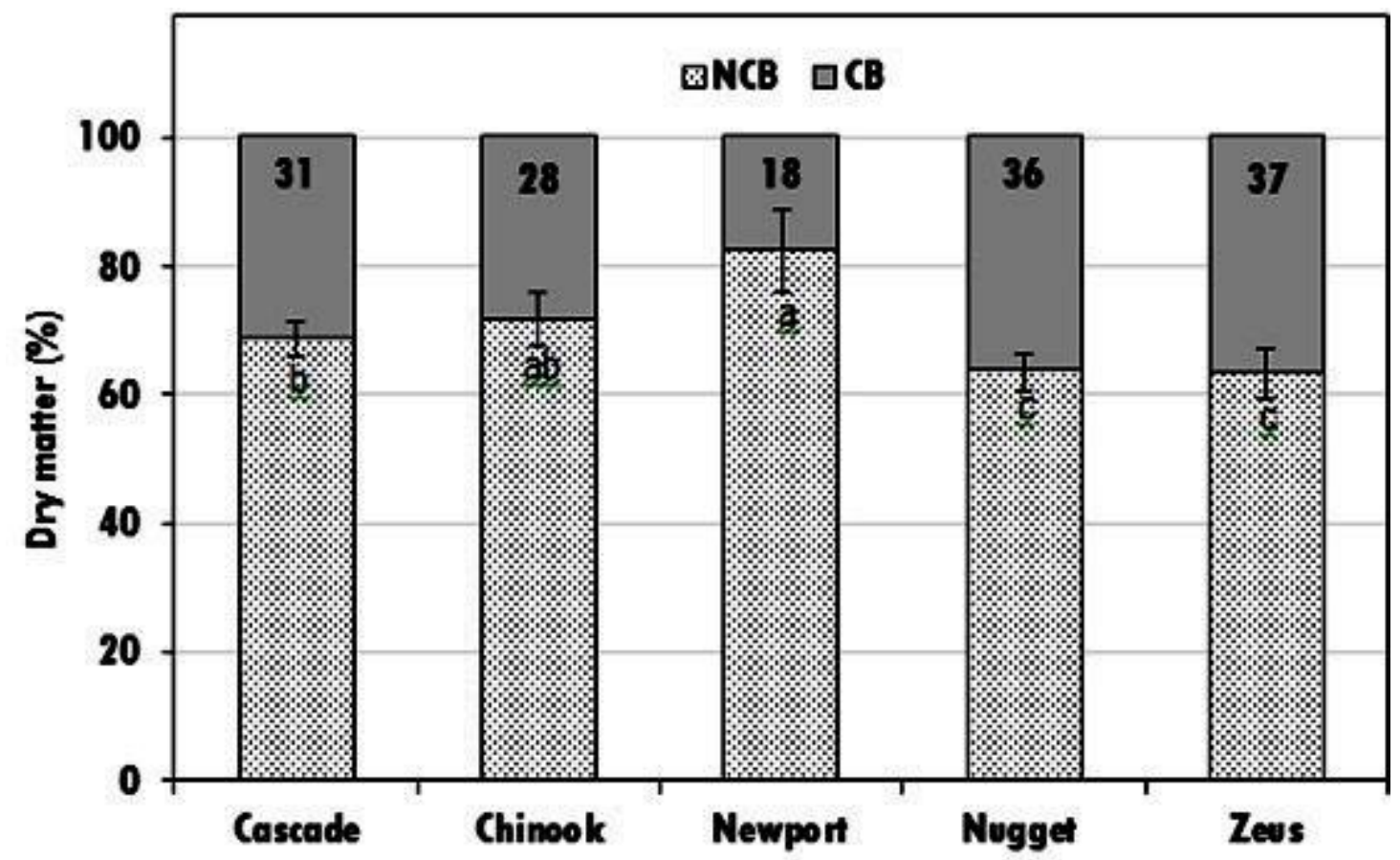

Figure 2. Dry matter distribution between cone and non-cone biomass at cone maturity in five hops (Humulus lupulus L.) varieties. (NCB: Non-cone biomass; CB: cone biomass). Bars represent standard deviation $(n=4)$ and letters denote significant differences between varieties at $p \leq 0.05$. 


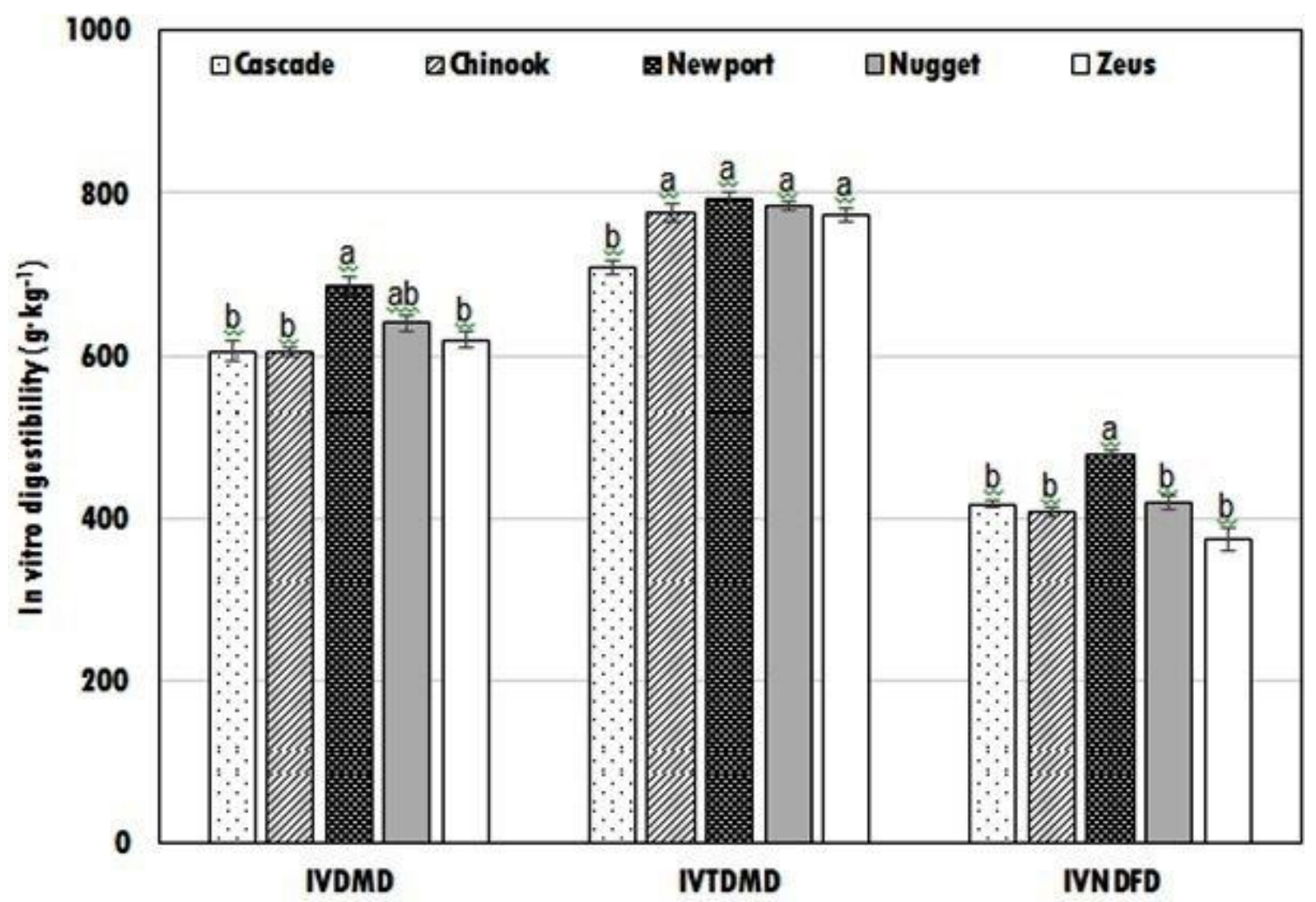

Figure 3. In vitro digestibility of non-cone biomass recovered at cone maturity from five hops (Humulus lupulus L.) varieties. Bars represent standard error $(n=4)$ and different letters across varieties denote significant difference $(p \leq 0.05)$.

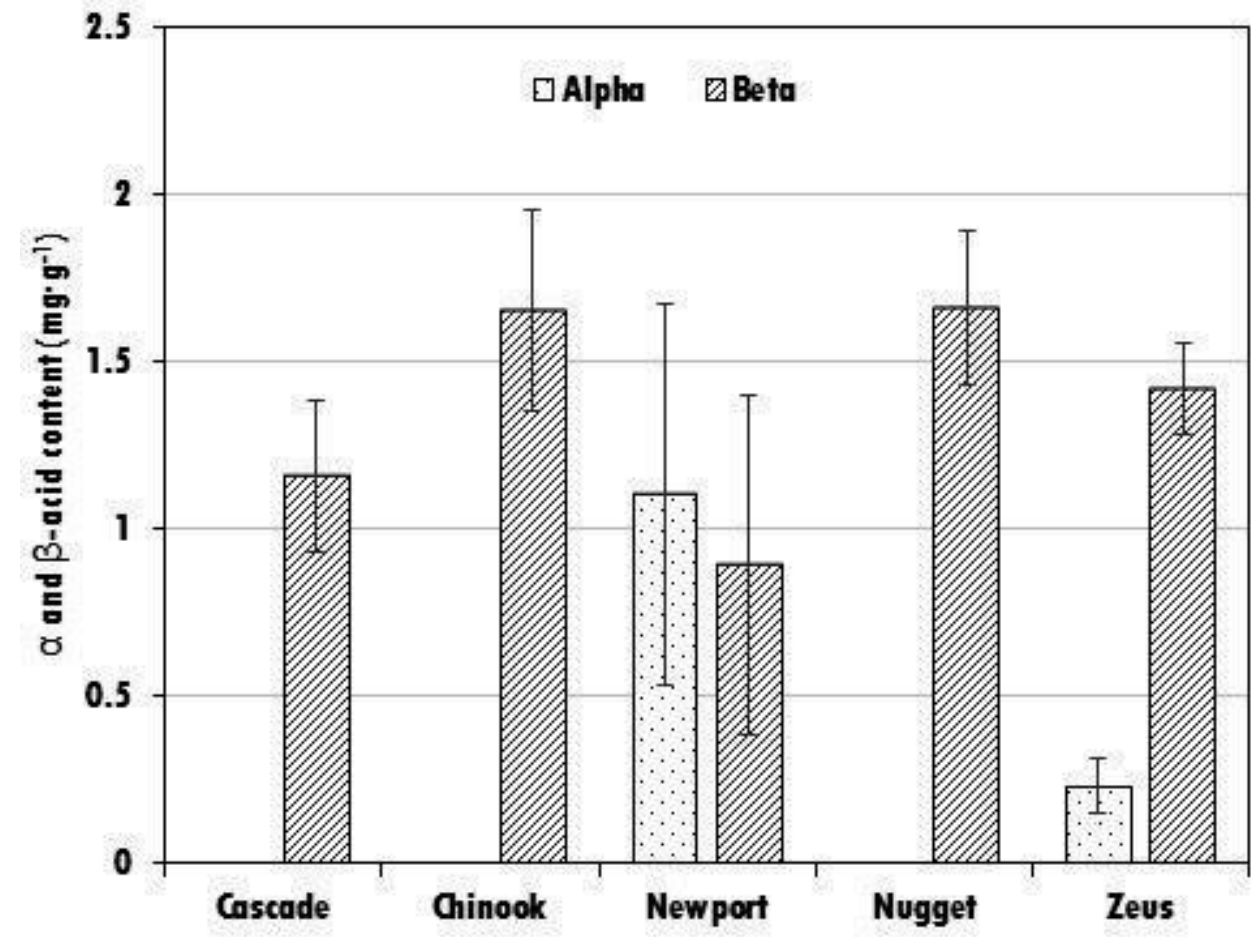

Figure 4. Alpha and $\beta$-acid content in in none cone biomass recovered at cone maturity from five hop (Humulus lupulus L.) cultivars. Bars represent standard deviation $(n=4) . ~ *$ Significantly different at $p \leq 0.05$. 
Table 1. Average temperature, precipitation and relative humidity at the research site during the 2017 growing season.

\begin{tabular}{|c|c|c|c|c|c|}
\hline \multirow{2}{*}{ Month } & \multicolumn{3}{|c|}{ Temperature $\left({ }^{\circ} \mathrm{C}\right)$} & \multirow{2}{*}{ Precipitation (mm) } & \multirow{2}{*}{$\begin{array}{l}\text { RH } \\
(\%)\end{array}$} \\
\hline & Mean & Min. & Max. & & \\
\hline March & 9.5 & -5.1 & 26.0 & 88.4 & 59.0 \\
\hline April & 18.3 & 0.7 & 31.5 & 32.3 & 67.2 \\
\hline May & 19.2 & 3.0 & 33.4 & 112.5 & 72.9 \\
\hline June & 24.0 & 11.2 & 33.7 & 73.4 & 71.5 \\
\hline July & 27.0 & 13.7 & 36.7 & 41.9 & 70.9 \\
\hline August & 24.6 & 13.9 & 34.0 & 66.5 & 73.6 \\
\hline Sept. & 21.3 & 9.5 & 32.7 & 11.7 & 73.8 \\
\hline October & 17.2 & -5.1 & 31.1 & 80.5 & 74.2 \\
\hline
\end{tabular}

Table 2. Nutritional and mineral composition of non-cone biomass recovered at cone maturity from five hop (Humulus lupulus) cultivars.

\begin{tabular}{|c|c|c|c|c|c|c|c|c|c|c|c|}
\hline Cultivar & $\mathrm{DM}$ & Ash & $\mathrm{CP}$ & $\mathrm{ADF}$ & aNDF & Sugar & Starch & $\mathrm{Ca}$ & $\mathrm{K}$ & $\mathrm{S}$ & $\mathrm{Mg}$ \\
\hline Cascade & $286.0^{\mathrm{ax}}$ & 137.4 & $244.3^{\mathrm{a}}$ & $294.6^{\mathrm{a}}$ & $397.2^{\mathrm{a}}$ & $49.7^{b}$ & 13.0 & $29.1^{\mathrm{c}}$ & $26.6^{\mathrm{a}}$ & $2.6^{\mathrm{a}}$ & $7.5^{\mathrm{bc}}$ \\
\hline Chinook & $272.0^{\mathrm{ab}}$ & 145.9 & $186.8^{c}$ & $212.5^{b}$ & $296.5^{b}$ & $65.3^{\mathrm{ab}}$ & 11.9 & $37.8^{\mathrm{a}}$ & $24.8^{\mathrm{ab}}$ & $2.3^{\mathrm{b}}$ & $7.7^{\mathrm{b}}$ \\
\hline Newport & $229.7^{c}$ & 140.3 & $199.8^{b}$ & $200.1^{\mathrm{b}}$ & $292.5^{b}$ & $74.3^{\mathrm{a}}$ & 12.7 & $33.9^{\mathrm{ab}}$ & $23.6^{b}$ & $2.5^{\mathrm{ab}}$ & $8.4^{\mathrm{a}}$ \\
\hline Nugget & $245.0^{b}$ & 129.1 & $204.5^{b}$ & $187.0^{\mathrm{b}}$ & $273.7^{b}$ & $78.7^{\mathrm{a}}$ & 21.6 & $32.4^{\mathrm{bc}}$ & $19.5^{\mathrm{c}}$ & $2.4^{\mathrm{ab}}$ & $6.9^{c}$ \\
\hline Zeus & $294.3^{\mathrm{a}}$ & 132.3 & $164.3^{\mathrm{d}}$ & $226.2^{\mathrm{b}}$ & $318.2^{\mathrm{b}}$ & $66.9^{\mathrm{ab}}$ & 13.0 & $35.7^{\mathrm{b}}$ & $25.4^{\mathrm{ab}}$ & $1.9^{\mathrm{c}}$ & $7.3^{b c}$ \\
\hline
\end{tabular}

DM: Dry matter; CP: Crude protein; ADF: Acid detergent fiber; aNDF: Neutral detergent fiber. ${ }^{x}$ Values within columns followed by different letters are significantly different at $p \leq 0.05$ (Tukey's HSD, $\mathrm{n}=4$ ).

\section{DISCUSSION}

Hops are grown for the unfertilized female flowers (also referred to as hop cones), used in brewing, and our data shows less than average yield for this key ingredient among tested cultivars. Ranging from a low of $0.3 \mathrm{Mg} \cdot \mathrm{ha}^{-1}$ for Newport to a high of $1.6 \mathrm{Mg} \cdot \mathrm{ha}^{-1}$ in Zeus, cone biomass yields were much lower than estimates for Michigan and the Pacific Northwest (Sirrine et al., 2014). This was further reflected in higher non-cone to cone biomass ratios among all varieties with the least cone production being observed in Newport (18\%) and the highest in Nugget and Zeus at $36 \%$ and $37 \%$, respectively. These numbers are contrary to those reported by Thomas (1967) who observed that cone biomass accounts for about $50 \%$ of above-ground dry matter accumulation at harvest.

The overall lower yield coupled with a higher proportion of non-cone biomass may be attributed to location. The VSU hop yard is located at a lower latitude with a shorter growing season compared with the north western states of the U.S. where hops are most productive. Failure by most bines to reach the top of the trellis and thus break apical dominance may also account for less side-arm growth and lower cone yield. Although dry matter partitioning is likely to change as the yard matures, these results underline the need for more work to identify varieties and agronomic practices most suited to Virginia and the mid-Atlantic.

The nutritive value of non-cone hop biomass and its potential for use as forage was considered from the perspective of dairy nutrition (Hoffman and Shaver, 2004; Hoffman, 2005; Paulson et al., 2008; Brown et al., 2017). Even at the lower end, non-cone biomass CP compares favorably with averages recorded for legumegrass hay (Hoffman and Shaver, 2004), suggesting it can be a good source of protein in livestock rations. Crude protein is a function of $\mathrm{N}$ content in forage and the generally high CP levels in hop biomass may be associated with the higher than average amounts of $\mathrm{N}$ fertilizer applied in the production of the crop (Neve, 1991). Recommended $\mathrm{N}$ rates for hops are 112-300 $\mathrm{kg} \cdot \mathrm{ha}^{-1}$ in the UK, Germany and the U.S., while P and $\mathrm{K}$ are supplied at $0-100 \mathrm{~kg} \cdot \mathrm{ha}^{-1}$ and $0-150 \mathrm{~kg} \cdot \mathrm{ha}^{-1}$, respectively, depending on residual levels in the soil (Mahaffee et al., 2009). This implies that processing of hop residue for use as livestock forage would represent significant value addition to minerals sequestered in noncone tissues.

Ash represents the total mineral content in forage and is found to range between $60-160 \mathrm{~g} \cdot \mathrm{kg}^{-1}, 70$ $160 \mathrm{~g} \cdot \mathrm{kg}^{-1}$, and $30-140 \mathrm{~g} \cdot \mathrm{kg}^{-1}$ of DM in legume-grass silages, legume-grass hay, and corn silage, respectively (Hoffman and Shaver, 2004). The relatively high ash content in non-cone hop biomass implies a lower 
proportion of non-fiber carbohydrates, a negative attribute in forage. Higher than normal ash in grass and legume forages is usually associated with silica from soil and other external contamination (Hoffman, 2005), but our hop forage samples were mostly free of non-plant contaminants suggesting high mineral sequestration in hop tissues. Results from forage and petiole (data not included) analysis relative to recommended sufficiency ranges for hop (Sirrine, 2016) show $\mathrm{Ca}$ and $\mathrm{Mg}$ concentrations to be slightly higher, and $\mathrm{P}, \mathrm{K}$ and $\mathrm{S}$ to be comparable to content in legume-grass hay. These levels are slightly lower that values recorded for alfalfa hays (Orloff and Putnam, 2007) and legume/grass silages (Hoffman and Shaver, 2004). Trace element data also shows that hop forage can be a good source of $\mathrm{Cu}, \mathrm{Mn}$, Fe and $\mathrm{Zn}$.

Sugar content in non-cone hop biomass ranged from a high of $78.7 \mathrm{~g} \cdot \mathrm{kg}^{-1}$ of DM in Nugget to a low of $49.7 \mathrm{~g} \cdot \mathrm{kg}^{-1}$ in Cascade with no significant difference in content among the top four varieties (Table 2). Starch content was much lower ranging from $11.9-21.6 \mathrm{~g} \cdot \mathrm{kg}^{-1}$ of DM with no significant differences observed between varieties. However, plant carbohydrate content has been shown to vary during the day due to imbalances in sugar synthesis and utilization (Bowden, 1968), and withincultivar carbohydrate content in hop biomass may vary depending on time of harvest. Starch and sugars comprise non-structural carbohydrates that are readily available to rumen microbes and are reported to improve $\mathrm{N}$ use efficiency in dairy cattle (Pelletier et al., 2010a). Compared to levels reported for other species, sugar content in non-cone hop biomass (49.7-78.7 $\left.\mathrm{g} \cdot \mathrm{kg}^{-1} \mathrm{DM}\right)$ is similar to that in forage grasses like reed canarygrass, brome grass, and Kentucky blue grass, and slightly higher than in alfalfa and red clover. Non-cone hop biomass starch content was found to be higher than in most pasture grasses and comparable to that in alfalfa and red clover (Pelletier et al., 2010a \& b). These results show that non-cone hop biomass can be an important source of non-structural carbohydrates in livestock diets.

Feed supplementation with hop cones or cone extracts to study their effect on ruminal fermentation and feed utilization have been conducted as discussed below, but we did not find any reports on controlled feeding to test palatability and in situ digestibility of non-cone biomass. However, findings by Al-Mamun et al. (2009; 2011) and reports of widespread sheep grazing to control sucker regrowth in New Zealand hop yards (Dodds, 2017) suggest general ruminant acceptance of non-cone hop forage. Furthermore, although the hop organic acids thought to be responsible for improving feed use efficiency in ruminants are found primarily in cone biomass, trace quantities are sequestered in leaf tissue (Čeh et al., 2007). Harvest losses (up to $10 \%$ of cone biomass in our case) may also contribute to elevated levels of the two organic acids in non-cone biomass. We found $0.9-1.7 \mathrm{mg} \cdot \mathrm{g}^{-1} \quad \beta$-acid in ground non-cone hop biomass after storage at ambient temperature for more than six months, suggesting long term stability of this compound in forage. This finding deserves further study as it suggests hop forage may improve feed utilization in addition to supplying key nutrients and trace elements to ruminants.

As mentioned above, the presence of low levels of hop organic acids in feed has been shown to modify rumen fermentation and to improve feed use efficiency in ruminants. At least two in vivo studies confirm the efficacy of hop organic acids as natural alternatives to synthetic growth promoters (ionophores) used in ruminant nutrition. Wang et al, (2010) found that supplementation of a steer diet with pelletized hop cones (cv. Teamaker) at a $\beta$-acid inclusion rate of $0-40 \mathrm{mg} \cdot \mathrm{kg}^{-1}$ of DM (growing diet) and $0-80 \mathrm{mg} \cdot \mathrm{kg}^{-1}$ of DM (finishing diet) resulted in a $6 \%$ increase in daily gain among steers receiving the highest hop treatment relative to the control diet. In fattening lambs, Blanco et al. (2018) report that inclusion of Nugget hop cones at a rate of 1.5 or $3.0 \mathrm{~g} \cdot \mathrm{kg}^{-}$ ${ }^{1}$ of total mixed ration (TMR), equivalent to $55.5 \mathrm{mg}$ and $110 \mathrm{mg} \cdot \mathrm{kg}^{-1} \beta$-acid of TMR modified rumen fermentation by increasing the proportion of acetate and decreasing that of propionate in a dose dependent manner. Higher acetate favors normal rumen $\mathrm{pH}$, while high propionate is commonly associated with metabolic disorders including reduced fiber digestion and rumen acidosis.

In vitro, amendment of rumen cultures with cone biomass from hop cultivars including Cascade (Narvaez et al., 2013), Willamette (Flythe, 2009), and Aurora and Dana (Lavrenčič et al., 2013) or isomerized hop extracts (Flythe, 2009; Flythe and Aiken, 2010) was observed to modify microbe composition and to regulate fermentation in a manner similar to synthetic antibiotics used to enhance feed utilization in ruminants. Furthermore, Harlow (et al., 2014) report that hop $\beta$-acids can inhibit fructan fermenting fecal bacteria, commonly associated with hindgut acidosis and laminitis in horses (Bailey et al., 2004). Based on existing literature, Flythe et al, (2017) recommend hop $\beta$-acids as a model natural alternative to synthetic ionophores in ruminant nutrition.

Conclusion and management implications: This report confirms the potential value of hop non-cone biomass as alternative forage. In addition to being a good source of protein, non-structural carbohydrates and minerals, hop forage holds great promise as a natural alternative to synthetic ionophores used to improve feed efficiency in ruminants by modifying rumen fermentation. This particular attribute merits further study to determine whether the same benefits deriving from the inclusion of cone biomass or cone extracts in ruminant rations can be realized through direct feeding of non-cone forage. Considering the scale of the U.S. hop industry, our findings could have huge economic implications. 
Acknowledgements: We are grateful to Dr. Anwar Hamama and Ms. Zaid Abraha-Eyob at the VSU Common Analytical lab for help with various analyses. This study was funded by a grant to the corresponding author from the USDA NIFA 1890 Institution Capacity Building Program\# 2015-38821-24384. This is a contribution of Virginia State University Research Station Article No. 363.

\section{REFERENCES}

Al-Mamun, M., K. Goto, S. Chiba, and H. Sano (2009). Responses of plasma acetate metabolism to hop (Humulus lupulus L.) in sheep. Int. J. Biol. Sci. 5(3):287-292.

Al-Mamun, M., A. Saito, and H. Sano (2011). Effect of ensiled hop (Humulus lupulus L.) residues on plasma acetate turnover rate in sheep. Anim. Sci. J. 82(3):451-455.

ASBC (2011). ASBC Methods of Analysis, $14^{\text {th }}$ Edition. American Society of Brewing Chemists. St. Paul, MN.

AOAC International (2016). Official Methods of Analysis of AOAC International. $20^{\text {th }} \mathrm{ed}$. AOAC International, Rockville, MD.

Apaydin-Varol, E., M. Kiliç, A. E. Pütün, G. Değirmen, and E. Pütün (2017). Humulus lupulus as a raw material for bio-oil production via slow pyrolysis. Gazi Univ. J. Sci. 30(2):111-122.

Bailey, S. R., C. M. Marr, and J. Elliott (2004). Current research and theories on the pathogenesis of acute laminitis in the horse. Vet. J. 167(2):129142.

Blanco, C., R. Bodas, L. Morán, J. Mateo, S. Andrés, and F. J. Giráldez (2018). Effect of hop (Humulus lupulus L.) inclusion in the diet for fattening lambs on animal performance, ruminal characteristics and meat quality. Food Res. Int. 108:42-47.

Bowden, D. M., D. K. Taylor, and W. E. P. Davis (1968). Water-soluble carbohydrates in orchardgrass and mixed forages. Can. J. Plant Sci. 48(1):9-15.

Brewers Association. (2018). National beer sales \& production data. Available from: https://www.brewersassociation.org/statistics/nat ional-beer-sales-production-data/.

Brown, A. N., G. Ferreira, C. L. Teets, W. E. Thomason and C. D. Teutsch (2017). Nutritional composition and in vitro digestibility of grass and legume winter (cover) crops. J. Dairy Sci. 101(3):2037-2047.

Čeh, B., M. Kač, I. J. Košir, and V. Abram (2007). Relationships between xanthohumol and polyphenol content in hop leaves and hop cones with regard to water supply and cultivar. Int. J. Mol. Sci. 8(9):989-1000.
Dodds, K. (2017). Hops: A guide for new growers. NSW Department of Primary Industries Job No. 14293. Available from: https://www.dpi.nsw.gov.au/_data/assets/pdf_fi le/0007/712717/hops-guide-for-newgrowers.pdf.

Ferreira, G. and D. R. Mertens. (2005). Chemical and physical characteristics of corn silages and their effects on in vitro disappearance. J. Dairy Sci. 88(12):4414-4425.

Flythe, M. D. and G. E. Aiken (2010). Effects of hops (Humulus lupulus L.) extract on volatile fatty acid production by rumen bacteria. J. Appl. Microbiol. 109(4):1169-1176.

Flythe, M. D. (2009). The antimicrobial effects of hops (Humulus lupulus L.) on ruminal hyper ammonia-producing bacteria. Lett. Appl. Microbiol. 48(6):712-717.

Flythe, M. D., I. A. Kagan, Y. Wang, and N. Narvaez (2017). Hops (Humulus lupulus L.) bitter acids: Modulation of rumen fermentation and potential as an alternative growth promoter. Front. Vet. Sci. 21(4):131

Gardea-Torresdey, I., M. Hejazi, K. Tiemann, J. G. Parsons, M. Duarte-Gardea and I. Henning (2002). Use of hop (Humulus lupulus) agricultural by-products for the reduction of aqueous lead (II) environmental health hazards. J. Hazard. Mater. 91(1-3):95-112.

Hall, M. B. (2009). Determination of starch, including maltooligosaccharides, in animal feeds: Comparison of methods and a method recommended for AOAC collaborative study. J. Assoc. Off. Agr. Chem. Int. 92(1):42-49.

Hall, M. B., W. H. Hoover, J. P. Jennings, and T. K. M. Webster. (1999). A method for partitioning neutral detergent-soluble carbohydrates. J. Sci. Food. Agr. 79(15):2079-2086.

Harlow, B. E., L. M. Lawrence, I. A. Kagan, and M. D. Flythe (2014). Inhibition of fructan-fermenting equine faecal bacteria and Streptococcus bovis by hops (Humulus lupulus L.) $\beta$-acid. J. Appl. Microbiol. 117(2):329-339.

Hejazi, M. (2001). New technology to remove toxic metal ions using hop biomass: Use of chemical modification and $\mathrm{x}$-ray absorption spectroscopy to determine the mechanism(s) of metal removal". ETD Collection for University of Texas, El Paso. AAI3035098. Available from: https://digitalcommons.utep.edu/dissertations/A AI3035098.

Hoffman, P. and R. Shaver (2004). A quick guide to understanding forage test results. Focus on Forage, 6, 1-2. Available from: https://fyi.extension.wisc.edu/forage/files/2014/ 01/QuickGuide-FOF.pdf . 
Hoffman, P. (2005). Ash content of forages. Focus on Forage, 7, 1-2. Available from: https://fyi.extension.wisc.edu/forage/files/2014/ 01/ASH05-FOF.pdf.

International Hop Growers' Convention (2017). Economic commission - Summary reports. Washington, D.C.

Lavrenčič, A., A. Levart, I. J. Košir, and A. Čerenak (2013). Influence of two hop (Humulus lupulus L.) varieties on in vitro dry matter and crude protein degradability and digestibility in ruminants. J. Sci. Food. Agr. 94(6):1248-1252.

López, M. L., J. L. Gardea-Torresdey, J. R. PeraltaVidea, G. de la Rosa, V. Armendáriz, I. Herrera, H. Troiani and J. Henning (2005). Gold binding by native and chemically modified hops biomasses. Bioinorg. Chem. Appl. 3(1-2):2941.

Mahaffee, W. F., S. J. Pethybridge, and D. H. Gent (eds.). (2009). Compendium of hop diseases and pests. The American Phytopathological Society, St. Paul, MN.

Narvaez, N., Y. Wang, and T. McAllister (2013). Effects of extracts of Humulus lupulus (hops) and Yucca schidigera applied alone or in combination with monensin on rumen fermentation and microbial populations in vitro. J. Sci. Food. Agr. 93(10):2517-2522.

Neve, R. A. (1991). Hops. London: Chapman and Hall.

Orloff, S. B. and D. H. Putnam (2007). Forage quality and testing. In: C.G Summers and D.H. Putnam, eds., Irrigated alfalfa management in Mediterranean and desert areas. Chapter 16. Oakland: University of California Agriculture and Natural Resources Publication, 8302.

Partelová, D., A. Šuňovská, J. Marešová, M. Horník, M. Pipíška, and S. Hostin (2015). Removal of contaminants from aqueous solutions using hop (Humulus lupulus L.) agricultural by-products. Nova Biotechnologica et Chimica, 14(2):212227.

Paulson, J., M. Raeth-Knight, J. Linn, and H. Jung (2008). Grass vs. legume forages for dairy cattle. Forage Focus-Dairy. Available from: http://www.midwestforage.org/pdf/323.pdf.pdf.

Pelletier, S., G.F. Tremblay, G. Bélanger, A. Bertrand, Y. Castonguay, D. Pageu, and R. Drapeu (2010a). Forage nonstructural carbohydrates and nutritive value as affected by time of cutting and species. Agron. J. 102(5):1388-1398.
Pelletier, S., G.F. Tremblay, A. Bertrand, G. Bélanger, Y. Castonguay, and R. Michaud (2010b). Drying procedures affect non-structural carbohydrates and other nutritive value attributes in forage samples. Anim. Feed Sci. Tech. 157(3-4):139150.

Pethick, D. W., D. B. Lindsay, P. J. Barker, and A. J. Northrop (1981). Acetate supply and utilization by the tissues of sheep in vivo. Brit. J. Nutr. 46(1):97-110.

SAS Institute Inc. (2015). SAS/STAT User's Guide 14.1. Cary, NC.

Siegle, L., and H. Scoggins (2017). 2016 Virginia Hop Grower Survey: Results. Virginia Cooperative Extension. Available from: https://pubs.ext.vt.edu/content/dam/pubs_ext_vt. ../ANR-292.pdf

Sirrine, R. (2016). The importance of testing hop fertility. Michigan State University Extension. Available from:

https://www.canr.msu.edu/news/the_importance of testing hop_fertility.

Sirrine, $\bar{R} . \bar{E}$. Lizotte, $\bar{D}$. Brown, T. O’Brien, and A. Leach (2014). Estimated costs of producing hops in Michigan. Michigan State University Extension Publication\# E3236.

Statham, M. (1984). The use of dried hop waste as a yolk colouring agent in poultry diets. Brit. Poultry Sci. 25(2):153-158.

Sutton, J. D., M. S. Dhanoa, S. V. Morant, J. France, D. J. Napper, and E. Schuller (2003). Rates of Production of acetate, propionate, and butyrate in the rumen of lactating dairy cows given normal and low-roughage diets. J. Dairy Sci. 86(11):3620-3633.

Thomas, G. G. (1967). Hop studies by the late I. H. Williams. Report of the Department of Hop Research. Wye College, 1966:63-67.

Wang, Y., A. V. Chaves, F. L. Rigby, M. L. He, and \& T. A. McAllister (2010). Effects of hop on ruminal fermentation, growth, carcass traits and shedding of Escherichia coli of feedlot cattle. Livest. Sci. 129(1-3):135-140.

Yang, W., T. Shimanouchi, M. Iwamura, Y. Takahashi, R. Mano, K. Takashima, T. Tanifuji, and Y. Kimura (2015). Elevating the fuel properties of Humulus lupulus, Plumeria alba and Calophyllum inophyllum L. through wet torrefaction. Fuel 146:88-94. 